\title{
Anpernirrentye: a Framework for Enhanced Application of Indigenous Ecological Knowledge in Natural Resource Management
}

\author{
Fiona J. Walsh ${ }^{1}$, Perrurle V. Dobson ${ }^{2}$ and Josie C. Douglas ${ }^{1}$
}

\begin{abstract}
Robust approaches to natural resource management (NRM) in indigenous cross-cultural contexts require coherent understandings of Indigenous Ecological Knowledge (IEK) systems. We synthesize a framework to represent the traditionally derived worldview of Arrernte Aboriginal people within which IEK is embedded. This is an ecology-focused worldview with three interrelated domains of knowledge that are intricately linked, comprising many complex dynamic elements that interact with each other. This worldview is from desert Australia but is relevant to those working in complex cross-cultural environments across Australia and internationally. The visual framework presented fills an important conceptual gap in IEK documentation being positioned at a mesoconceptual scale. Comparisons between this knowledge framework and social-ecological systems theory indicate similarities in systems thinking, in explicit links between people and ecology, and in the emphasis on processes and relationships through causal loops and feedbacks. Important differences lie in the inextricable integration of economic and spiritual domains in the Arrernte worldview. In Arrernte eyes, interrelationships between people, resource species, land, and spiritual domains are central to NRM. Scientific approaches commonly overlook or segregate elements of indigenous knowledge. The multiple values indigenous people attribute to species are often ignored or overridden, which contributes to decoupling within their knowledge system. Western scientists and natural resource managers are looking for better understandings of indigenous knowledge systems. The framework offers a tool that can be applied to both cross-cultural and intergenerational learning to improve NRM and people's well-being and sense of self.
\end{abstract}

Key Words: Aboriginal economy; Australia; biodiversity; bush foods; cultural values; desert; indigenous knowledge system; natural resource management; social-ecological system

\section{INTRODUCTION}

Integrating indigenous ecological knowledge (IEK) and western scientific knowledge requires an understanding of the mental models of both indigenous peoples and scientists. Different stakeholders in natural resource management (NRM) hold different mental models, and responding to these is a key aspect of effective NRM practice (Jones et al. 2012). The mental models of many individuals can be scaled up to be represented in a conceptual framework. This paper presents the conceptual framework of one desert Aboriginal group who synthesize many complex elements into a coherent worldview. They now live as a minority amidst the dominant populations and worldviews of Euro-Australian settlers.

Conceptual frameworks can be studied at macro-, meso- or microscales (Gibson et al. 2000, Strydom 2011). Similarly, IEK is explored at different conceptual scales. Macro- or bigpicture cognitive frameworks of IEK include knowledgepractice-belief frameworks (Berkes et al. 2000, Marika et al. 2009), definitional debates (Davis and Ruddle 2010) and "invisible losses," with the consequences of species decline contributing to loss of knowledge and profound cultural changes (Turner et al. 2008). Microscale descriptions and analyses of IEK are those most familiar to western-trained scientists active in NRM. They include, for example, speciesspecific knowledge (Nabhan 2000, Moller et al. 2004) and maps of land uses by individuals or family groups (Tobias 2010). Conceptual frameworks bridging from micro- to microscales are rare, but Roberts (2012) provides a sophisticated example of Maori mental maps.

Conceptual frameworks that bridge between macro- and microscales have been identified as important for improving cross-cultural communication (Berkes 2009, Lyver et al. 2009) and much needed for integration of science and indigenous knowledge in Australia (Ens et al. 2012, Muller 2012). Much documentation from Australia is fine scale and focused on the utility values of species (e.g., Latz 1995, Telfer and Garde 2006, Clarke 2007) or local resources (e.g., Central Land Council (CLC) 2011, Woodward et al. 2012). Aboriginal art provides prolific representations of the complex detail of IEK that is associated with places and/or species (Sutton 1988). However, this detail is inaccessible to most EuroAustralians. Rare examples of mesoscale conceptual frameworks include representations of seasonal constructs (Prober et al. 2011) and syntheses of place-based concepts (Hercus et al. 2002). Overall, few representations of Australian indigenous peoples' conceptual constructs transcend the particularities of specific places, seasons, or species.

This gap was highlighted for us by research and development activities over the past decade that have sought to commercialize central Australian plant species that are the 
Fig. 1. Arrernte lands surround Mparntwe (Alice Springs) and encompass about 150,000 km² of land. Coauthor, Veronica Dobson, is an Eastern Arrernte speaker. Arrernte lands neighbor other Arandic languages (Anmatyerr, Alyawarr, and Kayteye), Western Desert languages, (Pintupi/Luritja, Pitjantjatjara), and the Warlpiri language group. Large and small Aboriginal settlements are scattered across the central Australian region, with Alice Springs as their service center. Map by Brenda Thornley. Data from Institute for Aboriginal Development (IAD) Press (2002).

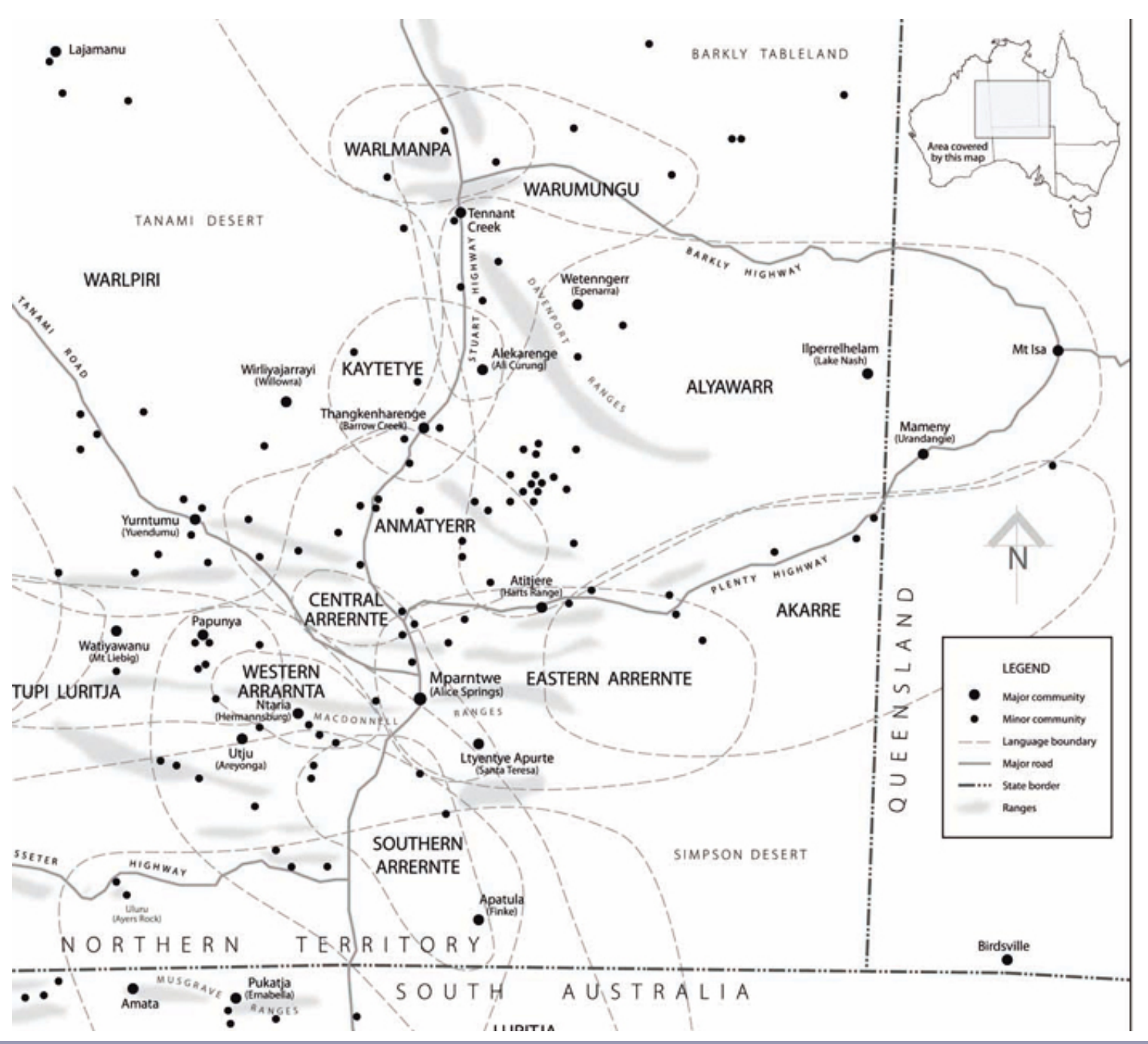

customary foods of indigenous people. Arid central Australia has a long-standing small-scale commercial trade in bushfoods (also known as wild foods or native foods) sourced from plants (Morse 2005, Walsh and Douglas 2011). Similarly, a suite of species from tropical Australia is being commercialized and domesticated (Gorman et al. 2006, Cunningham et al. 2008). Increasing commercialization and associated research have led some Aboriginal people to express concern about risks that the nonmonetary, cultural values of bushfood species will be overlooked or overridden, even in research and development projects intended to benefit Aboriginal people (McCarthy et al. 2010, Merne Altyerr-ipenhe Group et al. 2011). We realized that no existing representation of central Australian Aboriginal knowledge systems made visible the variety of cultural values associated with bushfood plants. This led us to analyze values that bushfood plants have to Arrernte people and to synthesize a conceptual framework that might help to explain these values to others.

Arrernte Aboriginal people's traditional estates are in arid central Australia and underlie the regional service town of Alice Springs (Fig. 1). Arrernte people are now settled in the town or sparsely scattered across the surrounding region. They live in the Aboriginal-tenured lands of extensive Land Trusts 
Fig. 2. The Anpernirrentye framework with the major domains (large circles) and associated elements or values of the plant species (small circles). These elements are equivalent to cultural values inherent in a plant species. There are many and complex interrelationships between a bush food species, Dreaming, country, and people. Thus, species have multiple connected values.

Erratum: In the PDF version of this paper, the format of figure 2 was changed after the original publication. The change was made on 5 November 2013.

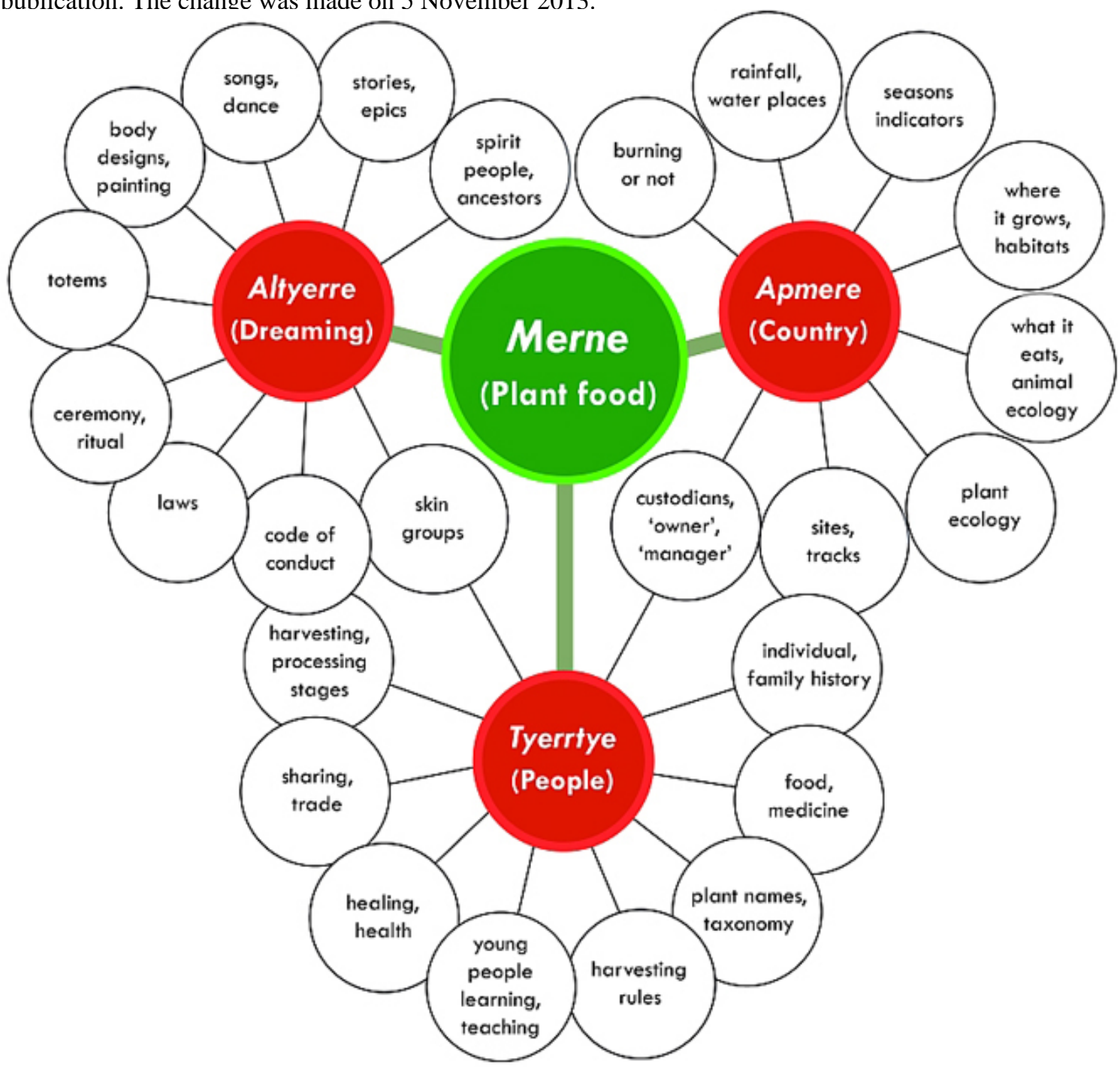

and numerous small land parcels. The Alice Springs population has 25,000 people including 4600 indigenous people from different language groups. In Alice Springs and the surrounding region, 2000 people speak Arrernte at home (Australian Bureau of Statistics 2012). Arrernte people are very much a minority population on their own traditional lands.

The region's social-ecological system has experienced very rapid change over the past 150 years. For many Arrernte people this has meant a complete shift in only a few generations from a hunter-gatherer economy to reliance for material needs on cash income sourced from social security entitlements and, less commonly, waged employment, artworks, and other minor sources (Austin-Broos 2009). Rapid cultural changes are driven by this economic shift, assimilation to dominant and powerful traditions of European colonizers, ongoing government interventions, and other forces (Altman and Hinkson 2007, Brown and Brown 2007). In central Australia, IEK is fragmented and endangered. Arandic languages and ecosystem health are both in decline and threatened (Hoogenrad in Johnson et al. 2006:35, Bastin and ACRIS 
Management Committee 2008). Nevertheless, Aboriginal traditions continue to be stronger in central Australia than in many other Australian regions.

Older Aboriginal people view young people as responsible for carrying knowledge forward for the benefit of future generations (Sherry and Myers 2002, Green et al. 2003, Dobson 2007). Young people are a large and rapidly growing proportion of the central Australian Aboriginal population (Australian Institute of Health and Welfare (AIHW) 2009). As the custodians and/or legally recognized owners of vast land tracts, younger Aboriginal people will be expected to play key roles in NRM as they mature. Yet, they now learn largely in classroom contexts rather than through direct experience and practice. We expect that access to conceptual frameworks of their own people's IEK systems will help younger Aboriginal people gain greater understanding of their own cultural traditions.

This paper offers a mesoscale conceptual framework that synthesizes an Arrernte worldview. Our overall aim is to develop a framework as a tool that supports greater crosscultural and intergenerational understanding. Our hope is that it will contribute to stronger respect for IEK, collaboration with IEK holders, and application of IEK in NRM.

The Anpernirrentye (Un-burn-i-rrin-cha) framework (Fig. 2) is the centerpiece of this paper. We first explain the methods used to synthesize the framework. Then, we explain the three major interrelated domains of an Arrernte worldview represented in the framework-Apmere (Country), Tyerrtye (People), and Altyerre (Dreaming, Creation time)-each of which links to and interrelates with the multiple elements of IEK that represent cultural values. We use Merne (bushfood plants) to show these values and interrelationships, drawing particularly on the IEK of Arrente and neighboring Aboriginal groups that relates to three species. We then explore applications of the framework to better care for and manage natural resources. As we discuss below, the framework has a number of characteristics that are novel from a scientific viewpoint. We compare the framework with social-ecological systems theory and then address our framework's broad applications within Australia beyond Arrernte people's estates.

\section{METHODS}

Researchers and indigenous people have both drawn attention to the need for greater rigor in IEK studies (Davis and Wagner 2003, Newman and Moller 2005, Davis and Ruddle 2010). Some researchers are concerned that the expertise of knowledge contributors cannot be critically examined in scientific contexts (Bohensky and Maru 2012); conversely, some indigenous people question the motivations and practices of researchers. Hence, we first introduce our knowledge of IEK systems and ourselves (see App. 1, Douglas and Walsh 2008, Merne Altyerr-ipenhe Group et al. 2011). We are a senior Arrernte woman (Dobson), an Aboriginal social researcher (Douglas), and a Euro-Australian ethnoecologist (Walsh; see Fig. 3). We note that, in research about Aboriginal Australia, the number of cross-cultural collaborations that extend to the point of coauthorship is increasing but remain few. Dobson is the primary source of our synthesis of an Arrernte framework as well as being a coauthor. Other accounts of desert peoples also informed our understanding (James 2005, Turner 2005b, Wallace and Lovell 2009, Walsh 2008, Turner and McDonald 2010).

Fig. 3. Arrernte ecological knowledge is acquired through practical experience but nowadays also partially shared in contexts distant from country and its species. (Left) Veronica Dobson with Kere Atyunpe, Varanus giganteus (Perentie) ca. 1960 (from Flynn 1963); (Middle) Josie Douglas (left) with family and friends on a hunting trip in central Arrernte land, the children show Kere Atyunpe hunted by their family, 2008 (Photo by J. Foster); (Right) Three authors prepare this paper during a focus meeting, 2008 (L-R: Josie Douglas, Fiona Walsh, Veronica Dobson) (Photo by H. Hueneke).

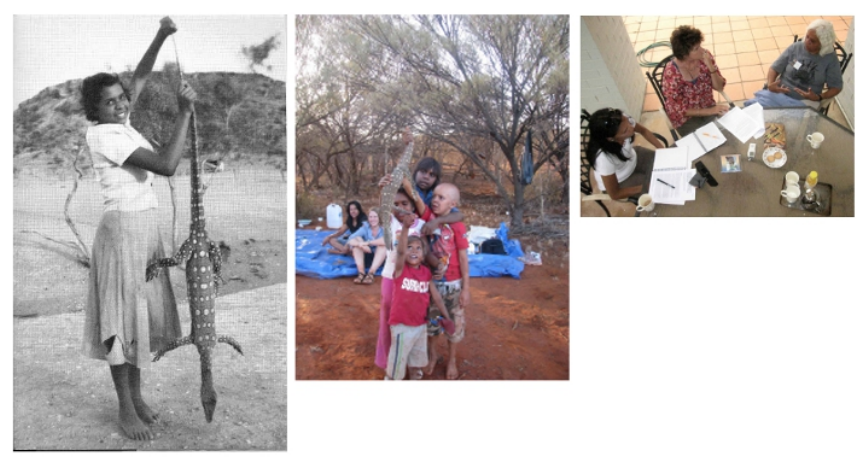

Within Australia, Dobson is highly regarded by Arrernte people and others as a senior and expert knowledge holder (App. 1). She is also widely respected for her ability to bridge the vast differences between desert Aboriginal and EuroAustralian worldviews. Furthermore, over more than two decades of work among Aboriginal people in central Australia, Walsh and Douglas have encountered few people who, like Dobson, have the exceptional integrative skills and metacognition that are required to explain Arrernte IEK as well as to collaborate through to coauthorship in synthesizing and presenting a conceptual framework. Similarly, Pawukurlpurlunu is a rare and gifted person. In the science domain of desert systems, there are also exceptional people capable of synthesizing and explaining complex social-ecological 
Table 1. Arrernte, English, and scientific names and synonyms for the species and the domain illustrated by each species, with example of related elements or values. Figure 8 illustrates these species.

\begin{tabular}{|c|c|c|c|c|c|}
\hline $\begin{array}{l}\text { Eastern Arrernte } \\
\text { name and synonyms } \\
\dagger\end{array}$ & $\begin{array}{l}\text { Common } \\
\text { English name } \\
\text { and synonyms }\end{array}$ & $\begin{array}{l}\text { Linnaean name, } \\
\text { author and family } \neq\end{array}$ & $\begin{array}{l}\text { Material values, } \\
\text { and preparation } \\
\text { techniques }\end{array}$ & $\begin{array}{l}\text { Conceptual } \\
\text { domain (Fig. 4) } \\
\text { illustrated by } \\
\text { species }\end{array}$ & $\begin{array}{l}\text { Example of how species is } \\
\text { associated with one of three main } \\
\text { domains and its elements }\end{array}$ \\
\hline $\begin{array}{l}\text { Ahakeye, } \\
\text { Ahnthwerrke }\end{array}$ & $\begin{array}{l}\text { Native currant }+ \text {, } \\
\text { Bush plum } \S \text {, } \\
\text { Wild plum, } \\
\text { Black plum }\end{array}$ & $\begin{array}{l}\text { Psydrax latifolia F. } \\
\text { Muell. ex Benth. } \\
\text { (was Canthium } \\
\text { latifolium), } \\
\text { Rubiaceae }\end{array}$ & $\begin{array}{l}\text { Ripe black, ca. 1- } \\
\mathrm{cm} \text { fruit hand- } \\
\text { picked carefully or } \\
\text { shrub gently } \\
\text { shaken so fruit falls } \\
\text { to cloth or cleared } \\
\text { ground. Fruit } \\
\text { preferably rinsed } \\
\text { so does not burn } \\
\text { mouth. Dried fruit } \\
\text { reconstituted. }\end{array}$ & $\begin{array}{l}\text { Altyerre } \\
\text { (Dreaming) }\end{array}$ & $\begin{array}{l}\text { Ahakeye Dreaming: 'powerful' } \\
\text { Species that could endanger people } \\
\text { if improperly harvested and } \\
\text { prepared; rules for careful harvest } \\
\text { practices protect the species and } \\
\text { harvesters; songline track > } 250 \mathrm{~km} \\
\text { long; major Ahakeye sacred } \\
\text { Dreaming sites; some in long-lived } \\
\text { mulga on peneplains }\end{array}$ \\
\hline Yalke, Irreyakwerre & $\begin{array}{l}\text { Bush onion } \S, \\
\text { Nut grass } \neq\end{array}$ & $\begin{array}{l}\text { Cyperus bulbosus } \\
\text { Vahl, } \\
\text { Cyperaceae }\end{array}$ & $\begin{array}{l}\text { Small tubers ca. } 1 \\
\mathrm{~cm} \text { dug from less } \\
\text { than } 20 \mathrm{~cm} \text { depth. } \\
\text { Eaten raw, lightly } \\
\text { roasted in hot } \\
\text { ashes. Also mixed } \\
\text { with water and } \\
\text { ground to a paste. }\end{array}$ & Tyerrtye (People) & $\begin{array}{l}\text { Major species in ancestral and } \\
\text { individual life history; preferred for } \\
\text { teaching young harvesters; special } \\
\text { food for babies and elderly; social } \\
\text { classification in skin groups on } \\
\text { Ampetyane and Ngale estates; } \\
\text { major trade item }\end{array}$ \\
\hline Akatyerre & $\begin{array}{l}\text { Desert raisin } \neq \text {, } \\
\text { Bush tomato }\end{array}$ & $\begin{array}{l}\text { Solanum centrale } \\
\text { J.M. Black, } \\
\text { Solanaceae }\end{array}$ & $\begin{array}{l}\text { Ripe yellow or } \\
\text { dried fruit ca. } 1.2 \\
\mathrm{~cm} \text {. Hand-picked } \\
\text { eaten raw. } \\
\text { Traditionally, } \\
\text { ground to paste, } \\
\text { formed to } 15-\mathrm{cm} \\
\text { balls, dried and } \\
\text { stored. }\end{array}$ & Apmer (Country) & $\begin{array}{l}\text { Aboriginal burn regimes to manage } \\
\text { Akatyerre fruit production; fruit } \\
\text { eaten by Emu (Dromaius } \\
\text { novaehollandiae) and Bush turkey } \\
\text { (Ardeotis australis), in turn, these } \\
\text { birds important food for Aboriginal } \\
\text { hunters }\end{array}$ \\
\hline
\end{tabular}

$\dagger$ Most commonly recorded name given here. Additionally, each species has part-specific terms (e.g. flowers, fruit ripeness stages).

$\ddagger$ as in Albrecht et al. (2007)

$\S$ as per local Aboriginal-English use

systems (e.g., Stafford Smith 2008); although they are rare, their work is highly regarded.

Our reliance on Dobson's mental model of IEK is open to criticism. This is partly because IEK is distributed knowledge, and a single individual will never know the entire knowledge system (Raffles 2002:326). However, in our view, there is a trade-off between the greater resources and time required for ideal rigor and loss of IEK through death of IEK experts and intensifying ecological degradation. Arguably, the pace of change demands compromises in scientific and ethnographic techniques (Johannes 1998, 2000).

We developed the Anpernirrentye framework during regular meetings and fieldwork over 5 years. The framework (Fig. 2) was synthesized from ongoing dialog and thematic analysis (Denzin and Lincoln 2003) of repeated topics raised in discussions about food plants. Dobson used the traditional medium of sand drawings to develop the framework diagram (Fig. 4). For a video showing these drawings, see Dobson et al. (2008). After Dobson had sketched a preliminary framework, we reviewed it with eight Aboriginal peers. The three authors then met to crosscheck and added detail to the framework (Fig. 3, right). We audio-recorded these meetings, and quotes were extracted for this paper. We also conducted five 1-day trips onto Arrernte country to locate and examine particular plant species, and through discussion, tested how the framework accounted for the cultural values of these species.

Our early research focused on one species, the Desert raisin (Solanum centrale), due to its significance in the bushfood industry (Bryceson 2008). Dobson then selected two other plant species that could highlight further domains, elements, and interrelationships of the emerging framework (Table 1). 
Fig. 4. Sand drawing by Veronica Dobson to illustrate Plant food-Dreaming-Country-People and the elements or values associated with one domain. This drawing of the four domains and some elements preceded that in Fig. 4. (From Dobson et al. 2008, Photo by W. Sati.)

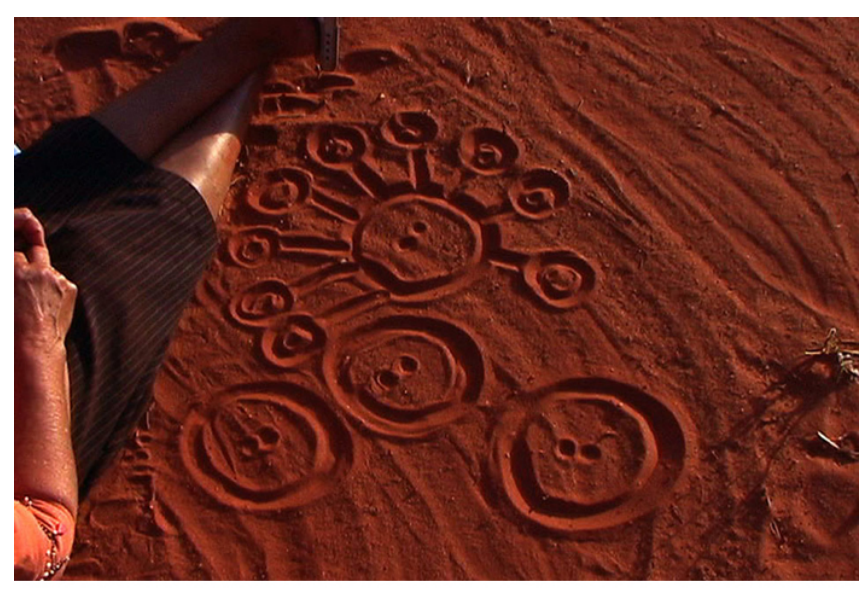

\section{The Anpernirrentye framework}

The Anpernirrentye framework (Fig. 2) provides a schematic synthesis of an Arrernte ecological knowledge system. Three major domains of an Arrernte worldview provide the structure. These are Apmere (Country), Tyerrtye (People), and Altyerre (Dreaming, Creation time). We have placed Merne (Bushfood plants) at the hub of the framework, where it links these domains. Alternatively, the relationships among these domains could be conceptualized using other resources significant to Arrernte people as the hub, such as Kere (Meat foods) or bush medicine species.

Anpernirrentye is the Eastern Arrernte term Dobson chose to best explain the framework (Fig. 2). Early in the development of the framework, she translated Anpernirrentye as:

The connections between plants, society, country, and laws and all things. It describes how these are related. These are related through skin and kin names. I want people to see how everything is connected. It is the connections that identify us as who we are.

\section{Country (Apmere) domain}

Apmere is defined as "country, land, region; an area of land and the things on it (trees, etc.); countryside" (Henderson and Dobson 1994:187). Apmere also means a camp, place, location, site, direction, or habitat or time-place positioning (Fig. 5). Stanner (1965:14) argued that, for the human-land relationships, "One is dealing, not with land, but with country, land already related to people." The Aboriginal-English term country alludes to the sociopolitical spatial associations of Aboriginal families to particular land tracts and species associated with those lands. Aspects of these associations between people and place are familiar to ecologists and NRM personnel because such people place themselves in a landscape when, for example, they camp or survey wildlife. Thus, they are connected to country through their own experiences. However, in Arrernte ecological knowledge, there are particular people who have custodial responsibility for the country or land area where a species occurs or can occur. To Arrernte people, the Apmere domain gives meaning to land because of the social relationships this domain engenders between people who live there or travel together.

Fig. 5. Apmere or Arrernte country at Atneperrke (John Hayes rockhole). Veronica (center) with three Arrernte generations associated with this sacred site. The Atneperrke site is named for the fat-covered intestines of certain mammals. (Photo by T. Nano.)

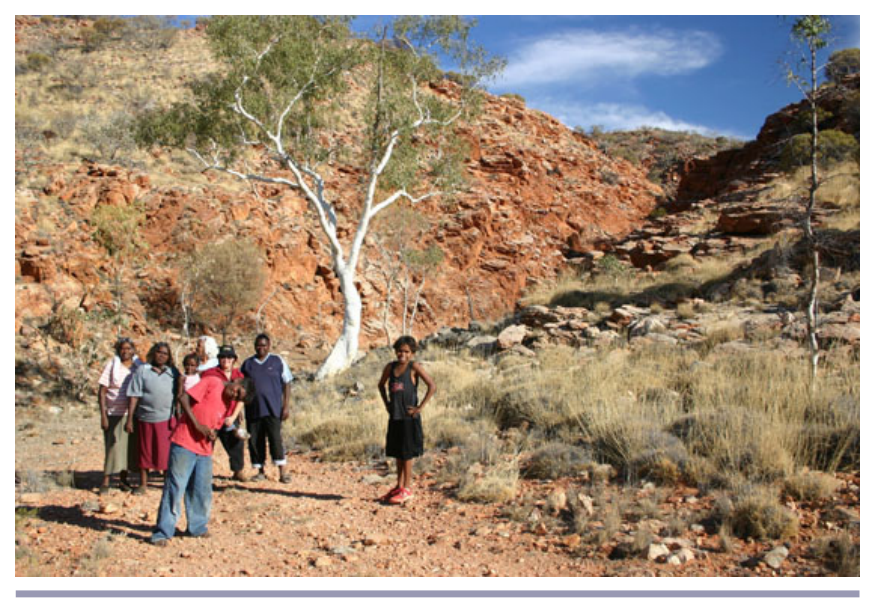

Elements or values in the Country domain include, as indicated in the framework (Fig. 2), sacred sites for the species, preferred habitats, the form and botanical characteristics of species, the animals that eat the species or have other ecological connections, the seasonal availability of a species, the species' responses to rainfall events and fire, and occurrence of the species in relation to water sources.

\section{People (Tyerrtye) domain}

The People domain (Fig. 2) translates from Tyerrtye, which is defined as "a person's body, people, Aboriginal people, a person's appearance, and humans" (Henderson and Dobson 1994:575). Skin, or classificatory kinship, groups dictate the social structure of desert Aboriginal societies (Dussart 2000). To Arandic and many central Australian Aboriginal groups, kinship governs relationships among people and biota. Dobson emphasizes that both the process and the content of Arrernte ecological knowledge are mediated through Arrernte kinship 
classes (Fig. 6). Plant species and individual people are related through at least three avenues: totemic or conception species, species occurring on country that a kinship group either owns or has managerial responsibility for, and species that have Dreamings (see below) that are also held by individuals. Plants have further relationships with people in some other central Australian groups. For example, among Warlpiri people, certain species belong to particular skin groups (Holmes and Jampijinpa 2013); M. Holmes, pers. comm. 22 September 2010).

Fig. 6. Arrernte kinship group names and relationships (from Henderson and Dobson 1994). This shows how kinship groups are connected by marriage and inherited by children of that marriage. Every individual has a skin group. These relationships define people's associations with particular land areas and certain species.

\section{Eastern and Central Arrernte Skin Names}

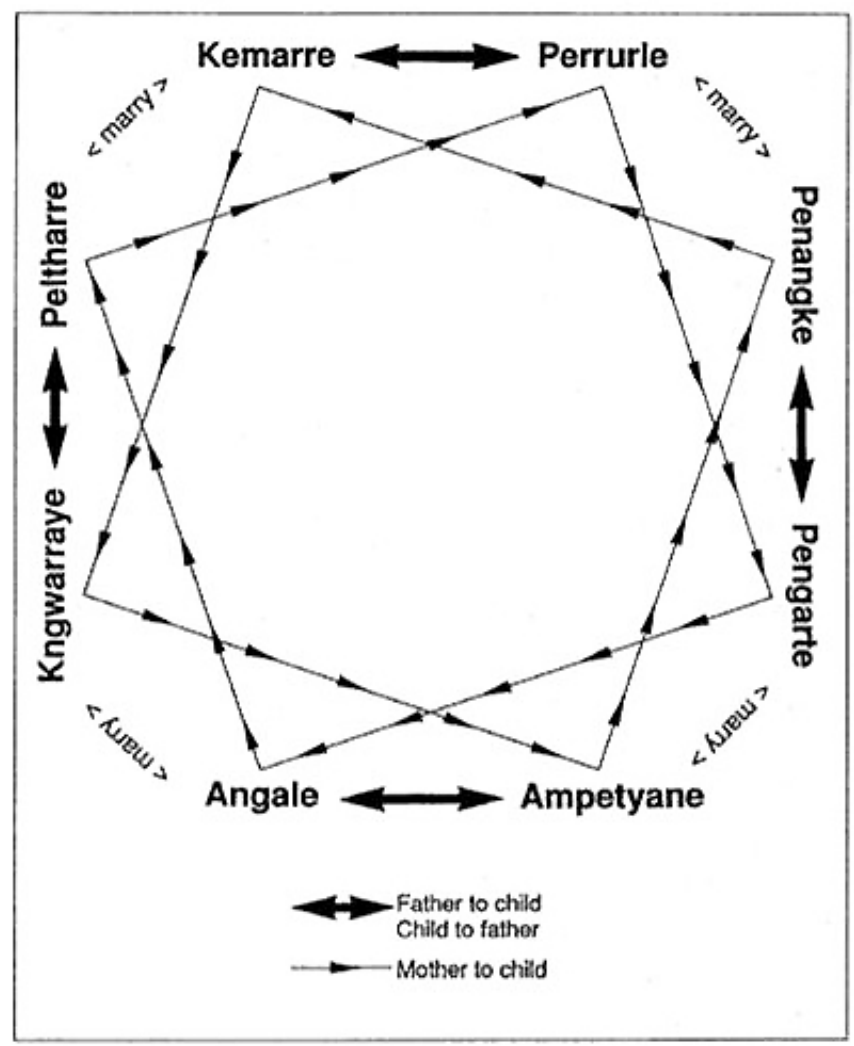

Elements or values in the People domain include, as indicated in the framework (Fig. 2), specific skin groups and custodial associations, the history of an individual or their family, how species are named and classified, the rules associated with species harvest, the species as suited to teaching young people or certain social cohorts, and the utility of the species as a product suited to social exchanges and trade among kin.

\section{Dreaming (Altyerre) domain}

The third domain is Altyerre, which is a very complex concept often misinterpreted by nonindigenous people (Green 2012). One of nine definitions of Altyerre in the Arrernte dictionary is "the Dreaming, Dreamtime; the creation of the world and the things in it, and its eternal existence" (Henderson and Dobson 1994:105).To Arrernte people, Altyerre includes moral codes of conduct, a prescribed system of inheritance, epic accounts of ancestral characters, tracks followed by characters, sacred sites, time past and present, a system of social behavior, and a life force (Strehlow 1965, Sutton 1995, Federal Court of Australia (FCA) 1999). Altyerre refers to the world as both continuous and permanent, for all time since its creation. Humans are not simply another part of this picture. Their presence, beliefs, and actions are vital to maintaining the spiritual and ecological structure and function of the world. Dobson sometimes calls Altyerre Creation-time because Dreaming can be misinterpreted as being "not real." Here, we use Altyerre in order to reduce simplification of a foundational concept.

One feature of Altyerre is its sacred sites or Altyerre places. These were created by characters who were plant or animal species, biophysical elements (fire, water), or astronomical features such as star constellations (Strehlow 1970). These characters molded the landscapes of Arrernte country. Some characters journeyed on songlines or Dreaming tracks that crisscross Arrernte lands and continue onto the land of neighboring groups (Toohey 1980) linking groups across Australia (Fig. 7). Songlines have multiple and complex purposes. For example, they are mnemonic codes that hold information on the ecology of landscapes and species used by hunter-gatherers (Newsome 1980). Songlines also carry teachings across people's countries and facilitate social and political connections between Aboriginal groups.

In Dobson's view, Altyerre encodes customary laws that are analogous to western laws from government.

This is how we perceive Country. How we tell it to young people and Europeans who want to learn. This is the Law we abided by. Like [you] got town laws, this is our Law.

Ethnographers have also observed this; as Myers explains, the Western Desert Pintupi "emphasize not only the norms or precedents established in The Dreaming, but also the sense of moral imperative it embodies" (Myers 1986:53). Although Western law has overridden much Aboriginal law in settled and town life, Dobson sees Arrernte law to be legitimate in 
Fig. 7. Schematic representation of Dreaming song lines or "tracks" (parallel lines) and sites (points) across Australia's lands and seas (from Mowaljarlai 1992). Ancestral characters as animals or plants formed these sites and/or tracks. The spatial connections show one means by which Aboriginal groups were linked across vast areas through ceremonies and knowledge exchange.

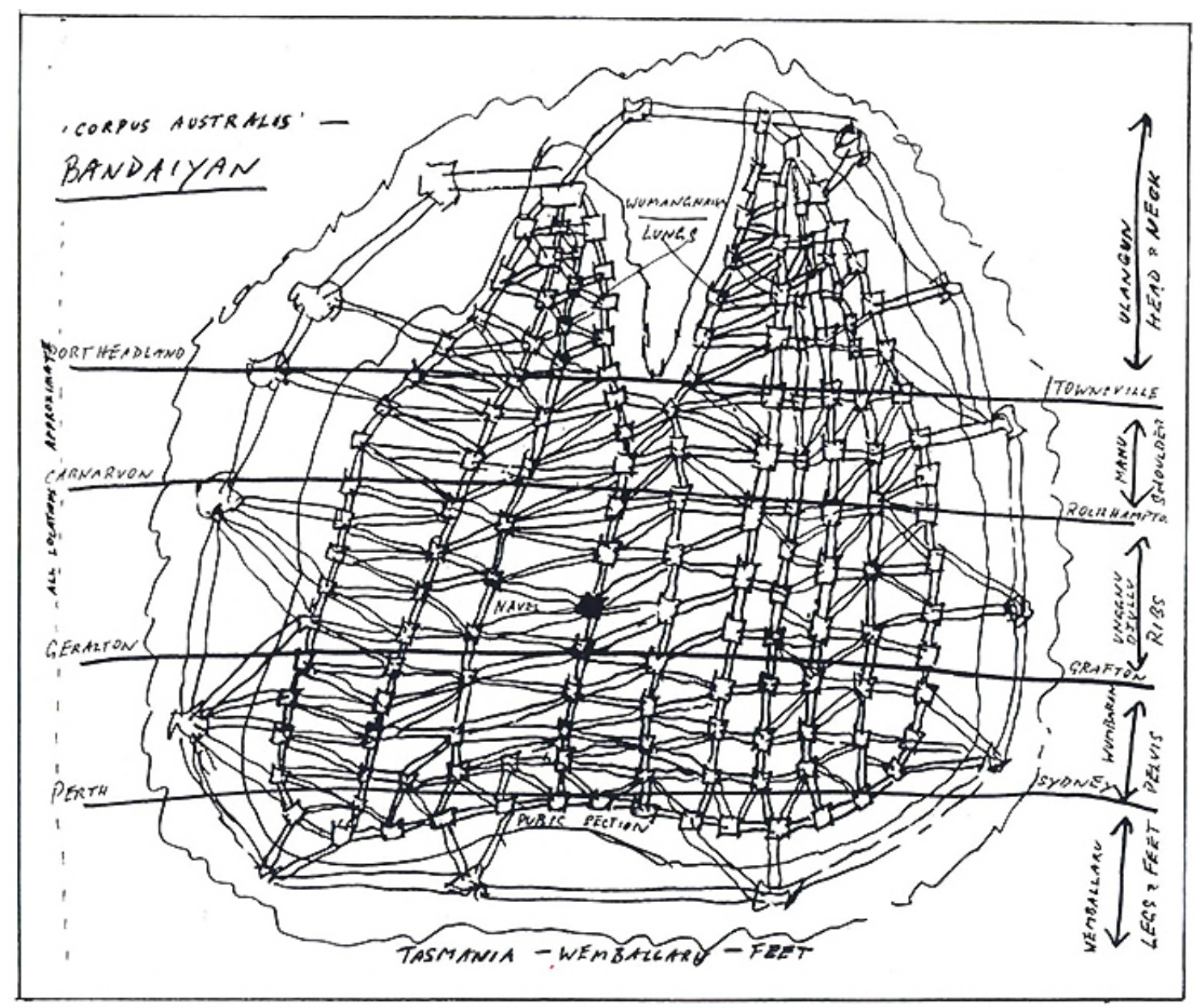

relation to Arrernte lands and resources. In Arrernte worldviews, grounded in Altyerre, the biophysical environment and its species offer a definitive moral order that calls for responsibility in human actions toward an environment that generates corresponding reactions from characters within the environment.

Elements or values in the Altyerre domain include, as indicated in the framework (Fig. 2), species who metamorphose from plant to spirit person or ancestral character, species that play roles in major epics or Altyerre stories, species symbolized in dance and song performance or ceremonies, species portrayed in artworks, species that have totemic value, and species that encode certain customary laws or codes of conduct.

\section{Merne: Bushfood Plant Species}

Merne (food from plants) represent a currency within the
Anpernirrentye framework, embodying value from the various elements in each domain. Food and other natural resources were the currency on which the nonmonetary economy of Arrernte people was based. Aboriginal people were directly and totally reliant in the recent past upon the species diversity of their lands. On Arrernte lands, about 30\% of plant species were used (estimated from Latz 1995, Department of Natural Resources, Environment, the Arts and Sport (NRETAS) 2009) in very many cases for food. Contemporary Aboriginal people often introduce Euro-Australians to their lands through bushfoods and even Aboriginal people who live in towns continue to use a suite of species although fewer than in the past.

Table 1 introduces three bushfood plant species selected by Dobson to highlight relationships among the three conceptual domains in the framework and their elements. These are 
Fig. 8. Examples of Arrernte merne (food plants) noted in this paper. (Left) ripe and unripe Ahakeye merne (Bush currant fruit) (Photo by J. Moloney); (middle) Yalke (Bush onion) before plant has dried, then tubers are suitable for harvest; (right) ripe Akatyerre merne (Desert raisin) fruit picked before dry stage by Eileen Bonney. (Photos by F. Walsh.) Table 1 names and describes these species.
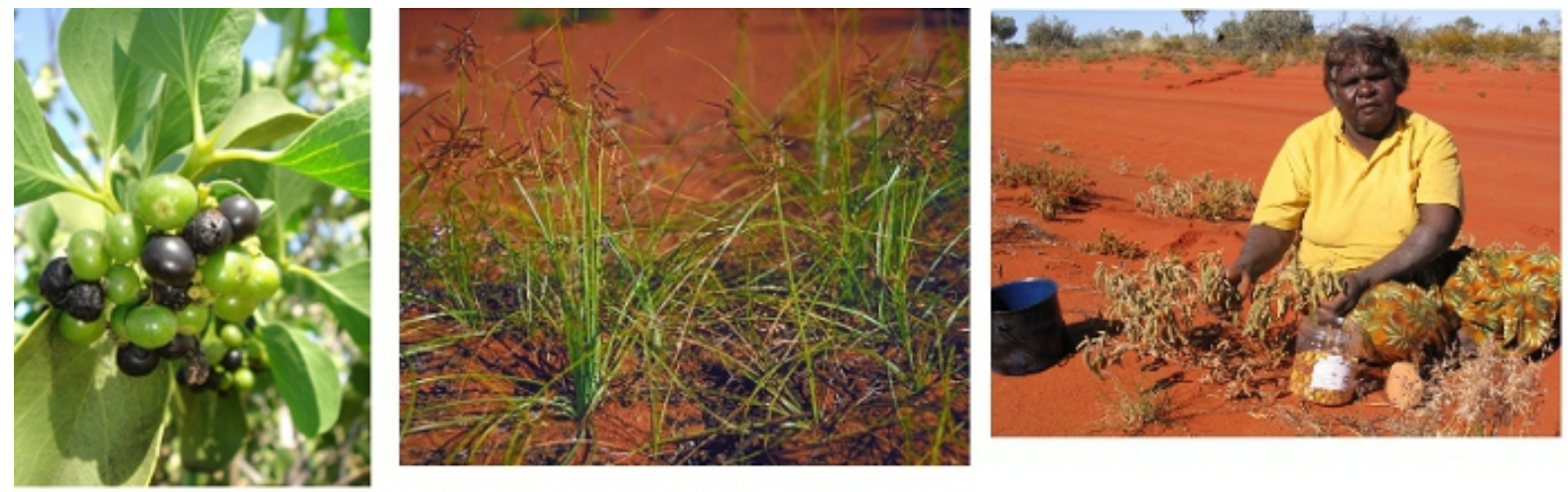

further outlined below for two of the species and described in more detail for the third species.

\section{Bush currant (Ahakeye)}

Bush currant (Ahakeye) is one species with a powerful Dreaming. As Dobson summarizes:

\section{Ahakeye is a sacred tree. It is a totem to Anmatyerr, Alyawarr and different people. Everyone needs to respect the plant.}

Out of respect for Ahakeye's power, specific protocols govern the way the plant is approached, who can collect it, and how the fruit is to be harvested. The power of the plant is sourced from its association with powerful ancestral beings. Sacred sites of the species are widely dispersed on, and beyond, a songline more than $250 \mathrm{~km}$ long (Toohey 1980). In the Anpernirrentye framework, this species illustrates how various Dreaming elements, including ancestor and totem, are linked to Country elements including sites and tracks and habitats, which in turn link to harvesting rules in the People domain.

\section{Bush onion (Yalke)}

Arandic people see Bush onion (Yalke) as a highly important species. It has associations that particularly highlight elements of the People domain. Yalke is associated with the origins and continuity of Kaytetye people to the north of Arrernte country (Fig. 1; Thompson 2003). It is a major food source. Older Arrernte people proudly remember Yalke as a plant they grew up eating and have attributed their strength to the plant (Rubuntja et al. 2002). Dobson described how the species helped teach young children to be independent in food harvesting. Yalke also had significant value as a major trade item as Dobson explains:
People traded Yalke. It was exchanged for Pituri [a narcotic species] and ochers. Sometimes today, bags are given from one group to another. When I was at Santa Teresa, we would receive a bag from family at Titjikala.

Yalke thus illustrates how, through the People domain of the framework, ancestral origins were linked to an individual's life history and to processes of trade that, in turn, sustained the reciprocal relationships essential to the social functioning of desert Aboriginal groups.

\section{Desert raisin (Akatyerre)}

Akatyerre (Desert raisin, Fig. 8) illustrates strong interconnections between Country, People, and Altyerre (Dreaming) domains. This species has probably long been the most valuable bushfood plant in central Australia (Latz 1995, Alyawarr et al. 2009) and continues to be so. Species attributes that contribute to its outstanding cultural values include its longevity, dried fruits that are retained on the plant and are also readily stored elsewhere, and high fruit production on plants that are regenerating after being burned. Desert Aboriginal people are likely to have manipulated the species over many generations to enhance its productivity.

Akatyerre illustrates the Country domain of the framework and also illustrates how multiple values of one species interlink elements of the framework and the three different domains. Arandic harvesters preferentially seek the plant on recently sand plains where it regrows after fire and rainfall (Fig. 9). The species is one of a number of species whose productivity was maintained by desert indigenous groups deliberately manipulating fire regimes (Walsh 1992, Latz 1995). Codependent foraging and burning persists in the Western Desert (Bliege Bird et al. 2008) and on Arandic lands (Edwards 
Fig. 9. The Akatyerre (Desert raisin) species selected to illustrate all three domains. (Left) On country, the production of Akatyerre is managed by fire that stimulate its regrowth and fruiting; (middle) On country in the Altyerr (Dreaming), the Emu and Turkey (Australian bustard) engaged in disputes over Akatyerre fruit. Biologically, the fruits are a favored food of these large birds also prized by Aboriginal hunters (Painting by Tilmouth and Abbott 2007); (right) Painting that depicts the creation ceremony for Desert raisin at Wirrirrpi on Ngaanyatjarra country (1.3 x 1.8 m painting (C) Pulpuru Davies, 1993, reproduced by kind permission Warburton Arts Project).
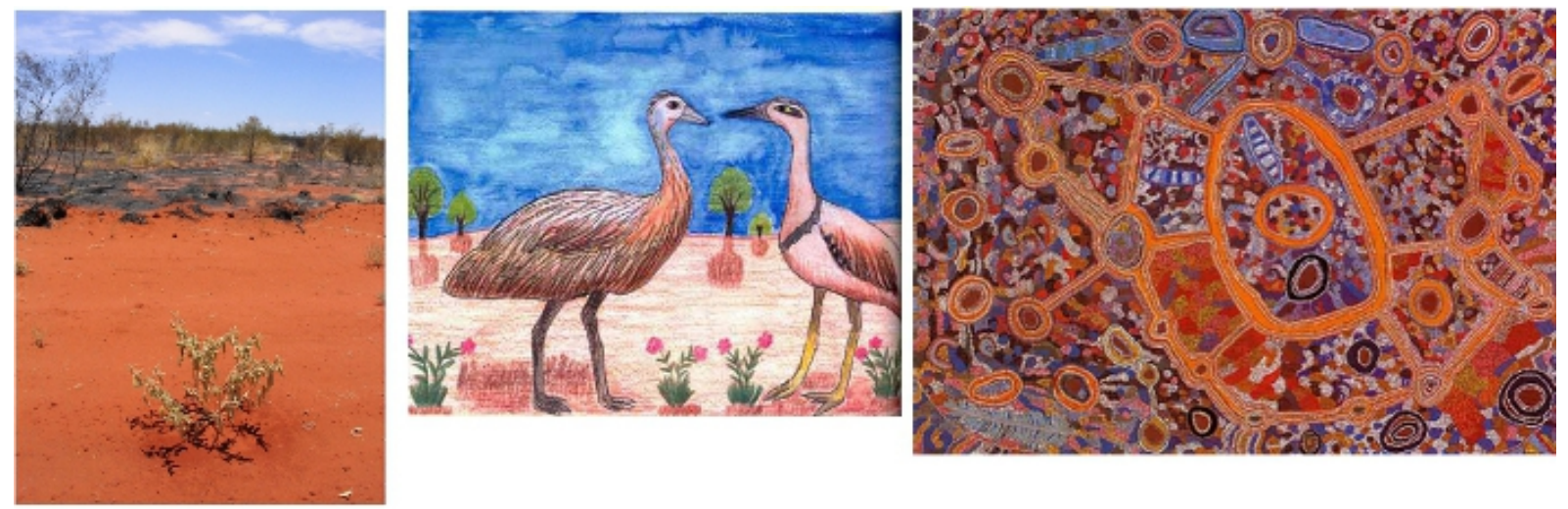

et al. 2008). These practices strongly link the Country and People domains in that burning is preceded by negotiation and decision making involving custodians who have the status of artweye (owner) and kwertengerle (manager) in relation to particular areas and species (Dobson et al. 2008, Alyawarr et al. 2009). On neighboring Warlpiri lands, the Dreamings associated with this plant species belong to men and women in the four skin groups of one Warlpiri patrimoiety (Nash and Simpson 1990:55).

Akatyerre is an important food for two large birds, the Australian Emu (Dromaius novaehollandiae) and Australian Bustard (Ardeotis australis), which are prized game species for desert Aboriginal hunters (Lowe 2002, Turner 2005a). Real-life ecological relationships between the fruit and the two bird species are re-expressed in socially based teachings from the Altyerre (Dreaming) domain (Fig. 9b, c). Within this domain, Akatyerre figures in songlines travelled by Emu and Bustard spirit ancestors. The birds transfigure to form landscape features. Furthermore, granitic boulders at certain places are interpreted by Warlpiri people as balls of dried Akatyerre abandoned by the Emu and Bustard ancestors as they fought (Campbell 2006). Teachings from the journey and drama of these birds exemplify the consequences of deceit, greed, and revenge (Warlukurlangu Artists 1992, Cook 2007). Akatyerre's links to animal species, landscape formations, and a moral code indicate that each domain in the Anpernirrentye framework is intertwined through many elements that continually engage with each other.

\section{Applications of the Framework}

Our peers respond positively to the Anpernirrentye framework, which indicates it has repeatability. The framework has been used and adapted to structure reports about microscale IEK concerning plants used by Arandic groups (Laramba et al. 2009, Amperlatwaty et al. 2010). Some Aboriginal colleagues and their nonAboriginal associates are using the framework in cross-cultural training curricula, translating Arrernte names for the domains to other indigenous languages as necessary. These emergent uses suggest that the framework is robust and applicable to other Aboriginal groups, either as it stands or with local adaptation. Aboriginal people who we have introduced to the framework variously characterize it as (a) portraying a worldview familiar but fragmenting; (b) reconstructing a past traditional worldview; and/or (c) presenting a worldview that could be adapted, and thus revitalized. We further discuss the framework's wider applicability beyond Arrernte lands below.

Indigenous ecological knowledge has contributed to environmental management and enterprise development outcomes in central Australia (e.g., Johnson et al. 2006, Ens et al. 2012). Practitioners have said to us that Arrernte knowledge has complemented science-derived information about lands and species in various NRM projects. However, when we investigated a selection of such projects, we found that very little of the richness and interconnected understandings inherent in Arrernte ecological knowledge was engaged. We reviewed five recent projects that involved Arandic people and other parties, such as ecological researchers. State, nongovernment or research agencies 
initiated these projects with various aims, spanning national park joint management planning, park visitor interpretative materials, cross-cultural environmental education, and threatened species monitoring. We sourced information on these projects through professional networks and reports (Pavey 2006, Tangentyere Landcare 2007, CLC 2008, Alyawarr et al. 2009, NRETAS 2009).

Less than eight elements of Arrernte ecological knowledge were apparent in any project, even though the Anpernirrentye framework indicates that more than 25 interrelated elements could be engaged. The elements of IEK incorporated into the projects tended to be from the Country domain. Elements from the People and Altyerre domains were apparent only rarely, if at all. Only one of the projects aimed to protect or promote a key cultural resource species despite such species being the foci of Arrernte ecological views. Senior knowledge holders working with Western scientists also want opportunities to teach traditional and modern knowledge to younger generations. Yet these opportunities are rarely realized in NRM projects (Ens et al. 2012).

The projects we examined operated predominantly within an NRM paradigm determined by government funding regimes and science-derived priorities. Cross-cultural intermediaries or brokers predominantly determine the modes of engagement in the NRM and employment sectors (Maru and Davies 2011). Small budgets and short time spans ( $<2$ years) in most of these projects undoubtedly made it hard for participants to develop cross-cultural relationships and understanding. We hope that future applications of the Anpernirrentye framework might increase the effectiveness of such projects in engaging Arrernte people and their IEK in cultural and natural resource management.

\section{DISCUSSION}

In Australia, indigenous people are now minority groups having been dominated by Europeans in new settler societies, as is also common to indigenous societies in New Zealand, Canada, and the United States. Most natural resource managers and ecologists struggle to understand and thus engage with indigenous people's worldview. Application of the Anpernirrentye framework potentially provides for greater understanding and more balanced attention to relationships between indigenous knowledge and scientific knowledge systems. The explicit recognition of indigenous worldviews is said to be a necessary precursor to IK and science knowledge integration studies (Bohensky and Maru 2012). The Anpernirrentye framework potentially contributes to the equity that is needed for knowledge integration to be a fulfilling engagement between experts. It seeks to bring indigenous ecological understandings to the fore so that they are not marginalized or trivialized. The framework is novel from a scientific view. Its potential lies in its applicability to knowledge integration beyond Arrernte people and their traditional estates, and its relationship to social-ecological theory.

\section{A Novel Framework from a Scientific Viewpoint}

The novelty of the Anpernirrentye framework to scientists and NRM practitioners derives from its focus on particular species to explore interconnected domains and elements. Interconnections from species to Country-People-Altyerre (Dreaming, Creation Time) are at the heart of Arrernte relationships to plants (or animals). The meaning of Anpernirrentye was previously recorded as encompassing only social relationships among humans (Henderson and Dobson 1994:150). However, Dobson's translation of the term in this paper includes "connections between plants, society, country, and laws and all things." She notes, as our examples indicate, that Anpernirrentye is not only about human social relationships because plants and animals are related to Aboriginal people through the same social system that classifies and structures relationships among human individuals. She explains that relationships between plant and animal species and Arrernte people have rarely been of interest to European people until recently. Even in native title and other land claim hearings, these interconnections have not been made explicit (e.g., FCA 1999).

Land claims and native title proceedings in Australia have focused on Aboriginal people's testimony about their connections to land through sacred sites, spiritual associations, and social relationships. These foci reflect the history of anthropological practice in Australia. Aboriginal uses of resource species have largely been ignored, which has contributed to the lack of awareness about the ecology of rich connectivity through species to country, social groups, and spirituality. In western Canada, for example, First Nations people's uses of resources like salmon species or western red cedar were the basis of treaties and land claims (Garibaldi and Turner 2004). Hence, the indigenous cultural values and connections of such resources are better known in Canada than those of equivalent resource species in Australia. The Anpernirrentye framework has the potential to enhance processes that may contribute to knowledge integration in NRM practice. It is a tool that can be used in cross-cultural and intergenerational dialog to encourage understanding of the interconnections between Country-People-Altyerre (Dreaming, Creation Time). The framework makes the interconnections, which are mediated by resource species, more visible and explicit.

Our representation of the framework positions resource species at the nexus between human, ecological, and spiritual domains, each with multiple elements or values. This representation echoes the conceptualization of IEK as that aspect of a cultural-framed belief system most directly arising from and concerned with food production and other material needs. (Davis and Ruddle 2010:885). The three species 
selected to illustrate the framework each have food value as well as many other cultural values and interlinkages to other species. As such they could be considered as cultural keystone species (Garibaldi and Turner 2004). Although these species have continued to be important to Arrernte people in contemporary times, traditionally desert Aboriginal people used a very wide range of species, an essential adaptation to unpredictable production driven by very variable rainfall economies (Devitt 1988, Walsh 2008), thus many other species could be represented within the framework.

Nonmonetary values of bushfoods are poorly articulated in central Australian NRM and associated regional economic development strategies. Other Aboriginal people, peers, and ourselves have seen these values be ignored or overridden in the nascent commercial bushfood industry. This catalyzed our development of the Anpernirrentye framework. We recognized that some Aboriginal harvesters choose to sell bushfoods, whereas others do not (Walsh and Douglas 2009, Yates 2009). For those who do, the monetary value of bushfoods has become a recent addition to customary cultural values and can also renew motivation for harvest and associated burning. Formal analysis of the Akatyerre (Desert raisin) bushfood value chain in central Australia, from harvester to consumer, identified only monetary values (Bryceson 2008). However, our analysis using the Anpernirrentye framework indicates more than 20 other elements of cultural value for the species. This contrast highlights the risk that commercialization, domestication, and horticultural production of bushfood species will contribute to ongoing invisibility and displacement of nonmonetary values. The risks to human and ecosystem health from this kind of invisible loss (Turner et al. 2008) intensify when Aboriginal custodians of bushfood species are disengaged from informed decision making about those species.

Natural resource management and ecological projects also often present difficulties in how they account for the nonmonetary value of species to Aboriginal people. Plant and animal resource species provide a vital point of mutual interest between indigenous people and ecologists (Wilson et al. 2010). Yet, NRM project designs commonly isolate Aboriginal IEK practice on country from the economic purposes of that practice. For example, there are many externally funded NRM projects that aim to revitalize traditionally derived Aboriginal burning practices. These projects are rarely explicit about the direct links between burning and hunting. Yet, from indigenous perspectives, key motivations for burning are to increase immediate hunting returns and postfire production of bushfood species. Hunting and gathering are critical to the functioning of an Aboriginal ecological system, even today.

We visualize the Anpernirrentye framework as a free-rotating multidimensional form where domains and elements shift and enlarge according to the context. However, the framework appears static on the two-dimensionality of paper. Furthermore, each element could be expanded to illuminate deeper understandings. For example, a species with healing and health values indicates further relevant elements such as one's spirit, causes of sickness, and healing remedies (Dobson 2007). Indigenous ecological knowledge studies often focus at the microscale on such rich detail. At this scale, researchers can lose sight of the full array of interconnections between knowledge domains that are embodied in a species. In contrast, the Anpernirrentye framework provides a novel mesoscale conceptualization that emphasizes connectivity. A synthesis of Maori mind maps by Roberts (2012) also emphasizes connectivity through complex relatedness between people and species. These mind maps encode ecological knowledge for utilitarian purposes and also to position oneself within the world.

Aboriginal knowledge holders and others are aware that the richness of microscale IEK is rapidly eroding through cultural and environmental change (Johnson et al. 2006, McCarthy et al. 2010, Douglas 2011), but it seems that a mesoconcept linking people-country-law is remarkably persistent. Knowledge holders have urged greater attention to intergenerational knowledge transmission. This framework highlights the importance of ensuring that IEK transmission builds understanding of the connectivity between knowledge domains. This connectivity in turn indicates a major similarity between the Anpernirrentye framework and social-ecological theory.

\section{Comparison to Social-Ecological Systems Theory}

We developed the Anpernirrentye framework (Fig. 2) through grounded and participatory approaches. In the process, we came to recognize similarities to social-ecological systems theory. These similarities particularly relate to feedbacks, multiple causal loops and the systems thinking inherent in the framework as exemplified by the complex integration of people, kin-based social systems, and land with its species and biophysical interactions.

As in social-ecological systems theory, Arrernte people are part of ecosystems, rather than outside agents. The lens of the Anpernirrentye framework indicates the social-ecological networks through which people are linked to the ecosystem (Anderies et al. 2006). These networks involve flows of knowledge, foods and other resources, and people. These networks are reinforced through social learning between neighboring groups, in species ceremonies, along countrybased songlines, and in the dual custodial responsibilities that people have for species and places, known in Aboriginal English as owner and manager.

Examining these networks through the Anpernirrentye framework highlights causal loops and feedbacks. Burning offers one example. Arrernte people know they burn to 
produce resources for themselves and that other species also benefit from the increased productivity that follows fire and subsequent rain. This enables people to hunt some individuals of those species, whereas others are left to reproduce. Further multiple causal relationships identified by Arrernte include the view that their ceremonies contribute to the reproduction of species. Such dimensions of Arrernte spiritual and moral codes arguably make this traditional knowledge system fundamentally irreconcilable with western scientific knowledge. Yet, these Arrernte belief systems are important in keeping knowledge linked to harvest and to burning and other practices. These beliefs and actions cycle around and around and are perpetuated to the benefit of both people and resource species. Arrernte and other Aboriginal people's alertness to feedbacks between the various domains and elements of their knowledge system are apparent in conversations that frequently interpret these interconnections, such as when people talk about things that birds are letting them know (Woods and Turpin 2008, Turner and McDonald 2010).

The Arrernte knowledge system directly links belief to the condition of people to the condition of their country. Dobson's observations of important plant resource species and habitats indicate their production is declining (Dobson and Nano 2005, Dobson et al. 2008). Declines in arid-zone biodiversity also continue to be reported from scientific monitoring (Bastin and ACRIS Management Committee 2008). These declines and their impacts are more serious from expert Aboriginal perspectives than is generally evident in scientific reporting. As the Desert raisin example shows, positive feedback loops between human manipulation, species production, and human nutrition are very tight. With settlement and the decline of Arrernte dependence on resource species, human manipulation is now less possible than in precolonial times.

In contemporary times, these feedbacks are perpetuated through activities such as harvest and burning for customaryfamily use, the self-motivated behaviors of Arrernte commercial bushfood harvesters, and externally funded NRM projects. When a species that has multiple and/or high cultural values declines or is no longer accessible, there are multiple repercussions (Parlee et al. 2005, Turner et al. 2008, Wehi and Wehi 2009a). Certain cultural values may be substitutable, such as food values from store-foods instead of from bushfoods (Altman 2003). However, other values are incommensurable, such as the classificatory kinship values of a species that is in a sister relationship to certain people.

Such losses have been argued to impact adversely on psychosocial and even biomedical health status (Turner et al. 2008). This suggests that decoupling of the inherent interrelationships between the domains and values represented in the Anpernirrentye framework has contributed to the premature mortality, extreme morbidity, and high suicide rates characterizing central Australian Aboriginal populations.
Recent research explains the biomedical condition of remotearea Aboriginal people partly in relation to their connectedness to land and culture (Rowley et al. 2008). In this paper, we delve deeper to illuminate some of the many complex associations with land and bushfoods that make up these connections. Aboriginal people's engagement with contemporary NRM has the potential to redress some of these impacts, if that engagement proceeds in ways that are mindful of Aboriginal worldviews (Davies et al. 2011). We consider that use of the Anpernirrentye framework as a tool to aid crosscultural and intergenerational communication may help build respect and collaboration.

\section{Applicability Within and Beyond Arrernte Lands}

The roles that species have in Arrernte people's economic, ecological, social, and spiritual lives constitute the Arrernte worldview and its belief system. Interconnections within the Anpernirrentye framework are recreated through practice, such as hunting to feed one's family, a school excursion where elders teach children on country, or surveying animal species by identifying their tracks in NRM projects. This recreation through action indicates cohesiveness between the Anpernirrentye framework and the practice-knowledgebelief concept that is a metascale one (Berkes et al. 2000, Berkes 2008). Relative to metascale concepts, the Anpernirrentye framework is at a mesoconceptual scale.

If IEK could be characterized as purely localized knowledge, as Wohling (2009) for example describes it, then the framework would not be applicable outside Arrernte country. However, his characterization of IEK fails to account for sociopolitical processes by which Aboriginal people spatially extend their knowledge across vast distances in Australia, for example, customarily through knowledge of songlines and in contemporary settings through meetings and conferences. This extended knowledge has allowed us to draw on IEK from outside Arrernte country in presenting the Anpernirrentye framework. Conversely, the worldview explained at a mesoscale by the framework is likely to be shared quite widely among Australian Aboriginal peoples, well beyond Arrernte lands. An Aboriginal English adage "us mob same but different" expresses this dialectic. A shared worldview allows Aboriginal groups to transcend difference and also pinpoint where differences lie.

Nevertheless, Dobson resists assumptions that the framework is applicable to other Aboriginal groups. In paraphrase, she says it is good if others choose to use or adapt the Anpernirrentye framework, as has started to happen, but it is contrary to Arrernte protocols to tell someone else that the framework represents their worldview. On a similarly cautionary note, the framework should not be upheld, integrated, or squashed to suit only western research paradigms at the expense of indigenous worldviews and collaborations, a risk noted by Agrawal (2002). 
The framework has application in cross-cultural communication, but its application in intergenerational teaching and learning is even more important. Cultures are dynamic, being transformed and modified by successive generations (Rogoff 2003, Greenfield 2004). Current generations of young Aboriginal people have far fewer opportunities to acquire the rich microscale IEK held by senior Aboriginal people who grew up reliant on bushfoods and other resources. This microscale information accumulates into a worldview. The illustrated framework can encourage young Aboriginal learners to explore IEK concepts that underpin their elders' and forebears' worldviews. Then, from that basis, they can build their own understanding of the cohesion and connectivity of elements important to an Aboriginal worldview. Appreciation of the multifaceted interconnections between resource species, people, country, and spirituality illuminated by the framework may also help foster young people's motivation to enhance connectivity in their contemporary social-ecological system. These connections are thought to be important to adaptive capacity (Berkes et al. 2000, Kassam 2010). Intergenerational applications of the framework could also be important to indigenous people in densely populated areas of Australia where cultural changes have been most profound, but where cultural commonalities connect inland desert to coastal peoples.

\section{CONCLUSION}

Understanding the different mental models of people and social groups is essential to improved NRM outcomes. This is especially challenging in the disparate cross-cultural contexts of indigenous and Euro-Australian people. The Anpernirrentye framework synthesizes a desert Aboriginal worldview that integrates people, country, and spiritual domains. It fills an important conceptual gap in Australian IEK documentation in Australia, being at the mesoconceptual scale. We have derived the framework from current and recent oral, experiential, and figurative traditions of desert Aboriginal people, drawing particularly on the deep knowledge and metaconceptual skills of the senior and respected Arrernte IEK holder who has coauthored this paper.

The framework reveals a distinctly different worldview to that of scientists and Euro-Australians, many of whom hold conventional NRM concepts that are underpinned by a conceptual separation between nature and culture, wherein resource management is characterized as something that people do from outside the ecosystem. The framework facilitates understanding that the interconnections between plant (or animal) species and Aboriginal people are more multifaceted and deeply interconnected than previously documented.

Desert social-ecological systems may be strengthened by the more comprehensive incorporation of Aboriginal views and values into NRM. Our visual presentation of an Arrernte conceptual framework gives scientists and NRM practitioners an opportunity to better understand Arrernte views. We expect the framework will help inform decision making and processes concerned with integration of IEK and science. The framework will also be of intracultural benefit as a tool to aid those who teach and learn in intergenerational contexts within and beyond Arrernte country.

Responses to this article can be read online at: http://www.ecologyandsociety.org/issues/responses. $\mathrm{php} / 5501$

\section{Acknowledgments:}

We respect the elders who passed on traditional knowledge and the future generations who seek to learn it. CSIRO and Charles Darwin University contributed funds to the work reported in this publication. Funding from the Australian Government Cooperative Research Centres Program through the Desert Knowledge CRC also supported the research. The views expressed herein do not necessarily represent the views of these parties. Members of the Merne Altyerr-ienhe (Food from the Creation-time] Reference Group also directed us in our research, particularly M. K. Turner(OAM), Lorna Wilson, Rayleen Brown, and Gina Smith. Linguists Jenny Green, Mary Laughren, David Moore, Linda Rive, and Myfany Turpin provided information and assistance. The responsibility for interpretations remains ours. We thank Jocelyn Davies, Ashley Sparrow, Ro Hill, and Noah Pleshet who provided comments on early drafts. We are grateful to Henrik Moller for his positive and insightful reviews, two anonymous reviewers, and the editors for their constructive recommendations.

\section{LITERATURE CITED}

Agrawal, A. (2002), Indigenous knowledge and the politics of classification. International Social Science Journal 54: 287297

Albrecht, D. E., A. W. Duguid, H. Coulson, M. G. Harris, and P. K. Latz. 2007. Vascular plant checklist for the southern bioregions of the Northern Territory: nomenclature, distribution and conservation status. Northern Territory Herbarium, Northern Territory Government, Darwin, Australia.

Altman, J. 2003. People on country, healthy landscapes and sustainable Indigenous economic futures: the Arnhem Land case. The Drawing Board: An Australian Review of Public Affairs 4(2):65-82.

Altman, J., and M. Hinkson, editors. 2007. Coercive reconciliation: stabilise, normalise and exit Aboriginal Australia. Arena Publications, Melbourne, Australia.

Alyawarr, speakers from Ampilawatja, F. Walsh, and J. 
Douglas. 2009. Angka Akatyerr-akert-ADesert raisin report. Report in Alyawarr and English. Desert Knowledge Cooperative Research Centre, CSIRO, and Charles Darwin University, Alice Springs, Australia.

Amperlatwaty, Arnkawenyerr, and Arlparra senior knowledge holders, Alyawarr language speakers, and J. Moloney. 2010. Anaty [Bush potato] report: Alyawarr families regularly hunt for Anaty. Tangentyere Landcare, Alice Springs, Australia.

Anderies, J., B. Walker, and A. Kinzig. 2006. Fifteen weddings and a funeral: case studies and resilience-based management. Ecology and Society 11(1): 21. [online] URL: http://www. ecologyandsociety.org/vol11/iss1/art21/

Austin-Broos, D. 2009. Arrernte present, Arrernte past: invasion, violence and imagination in indigenous central Australia. University of Chicago Press, Chicago, Illinois, USA and London, UK. http://dx.doi.org/10.7208/chicago/978022$\underline{6032658.001 .0001}$

Australian Bureau of Statistics (ABS). 2012. 2011 Census QuickStats: Alice Springs indigenous area. Canberra, Australia. [online] URL: http://www.censusdata.abs.gov.au/

Australian Institute of Health and Welfare (AIHW). 2009. A picture of Australia's children 2009. Australian Government, Australian Institute of Health and Welfare, Canberra, Australia.

Bastin, G., and ACRIS Management Committee. 2008. Rangelands 2008-taking the pulse. Published on behalf of the Australian Collaborative Rangeland Information System (ACRIS) committee by the National Land and Water Resources Audit, Canberra, Australia. http://www.environment. gov.au/land/publications/acris/report08.html

Berkes, F. 2008. Sacred ecology. Routledge, New York, New York, USA.

Berkes, F. 2009. Evolution of co-management: role of knowledge generation, bridging organizations and social learning. Journal of Environmental Management 90(5):16921702. http://dx.doi.org/10.1016/j.jenvman.2008.12.001

Berkes, F., J. Colding, and C. Folke. 2000. Rediscovery of traditional ecological knowledge as adaptive management. Ecological Applications 10(5):1251-1262. http://dx.doi. org/10.1890/1051-0761(2000)010[1251:ROTEKA]2.0.CO;2

Bliege Bird, R., D. W. Bird, B. F. Codding, C. H. Parker, and J. H. Jones. 2008. The "fire stick farming" hypothesis: Australian Aboriginal foraging strategies, biodiversity, and anthropogenic fire mosaics. Proceedings of the National Academy of Sciences of the United States 105(39):1479614801. http://dx.doi.org/10.1073/pnas.0804757105

Bohensky, E., and Y. Maru. 2012. Indigenous knowledge, science and resilience: what have we learnt from a decade of international literature on "integration"? Ecology and Society 16(4):6. http://dx.doi.org/10.5751/ES-04342-160406

Brown, A., and N. J. Brown. 2007. The Northern Territory intervention: voices from the centre of the fringe. Medical Journal of Australia 187(11/12):621-623.

Bryceson, K. P. 2008. Value chain analysis of bush tomato and wattle seed products. DKCRC Working Paper 40. Desert Knowledge Cooperative Research Centre, Alice Springs, Australia.

Campbell, L. 2006. Darby: one hundred years of life in a changing culture. ABC Books, Sydney, Australia.

Central Land Council (CLC). 2008. The Central Land Council annual report 2007-2008. Central Land Council, Alice Springs, Australia.

Central Land Council (CLC). 2011. Handing down knowledge: intergenerational transfer of indigenous ecological knowledge (IEK), southern NT 2008-2010, interactive $C D$. Central Land Council, Alice Springs, Australia.

Clarke, P. 2007. Aboriginal people and their plants. Rosenberg Publishing, Melbourne, Australia.

Cook, J. N. (J. Green, compiler.) 2007. Anengkerr angkety: dreaming stories. Batchelor Press, Alice Springs, Australia.

Cunningham, A. B., S. Garnett, J. Gorman, K. Courtney, and D. Boehme. 2008. Eco-enterprises and Terminalia ferdinandiana: "best laid plans" and Australian policy lessons. Economic Botany 63(1):16-28. http://dx.doi.org/10.1007/ s12231-008-9055-2

Davies, J., D. Campbell, M. Campbell, J. Douglas, H. Hueneke, M. LaFlamme, D. M. Pearson, K. Preuss, J. Walker, and F. Walsh. 2011. Attention to four key principles can promote health outcomes from desert Aboriginal land management. The Rangeland Journal 33(4):417-431. http:// dx.doi.org/10.1071/RJ11031

Davis, A. and K. Ruddle. 2010. Constructing confidence: rational skepticism and systematic enquiry in local ecological knowledge research. Ecological Applications 20(3):880-894. http://dx.doi.org/10.1890/09-0422.1

Davis, A., and J. R. Wagner. 2003. Who knows? On the importance of identifying "experts" when researching local ecological knowledge. Human Ecology 31(3):463-489.

Denzin, N., and Y. Lincoln. 2003. Strategies of qualitative enquiry. Second edition. Sage Publications, Thousand Oaks, California.

Department of Natural Resources, Environment, the Arts and Sport (NRETAS). 2009. West MacDonnell (Tyurretye) National Park draft joint management plan-fresh ideas, real 
results. Parks and Wildlife Service of the Northern Territory; NT Department of Natural Resources, Environment, the Arts and Sport, Alice Springs, Australia. [online] URL: http:// www.parksandwildlife.nt.gov.au/ data/assets/pdf file/0011/3170/ Draft West Macs JMPlan.pdf

Devitt, J. 1988. Contemporary Aboriginal women and subsistence in remote arid Australia. Dissertation, Department of Anthropology and Sociology, University of Queensland, Brisbane, Australia.

Dobson, V. P. 2007. Arlhe-kenhe Merrethene: Arrernte traditional healing. IAD Press, Alice Springs, Australia.

Dobson, V. P., and A. Nano. 2005. Apmere apwerte urrtharenye-kenhe: the country of the limestone people. Central Land Council and Northern Territory Parks and Wildlife Service, Alice Springs, Australia.

Dobson, V. P., F. Walsh, and W. Sati. 2008. Anpernirrentye: relationships between bush foods, creation laws, people, country and all things, illustrated by three plants. DVD 13'22". Desert Knowledge CRC and CSIRO, Alice Springs, Australia. [online] URL: http://desertknowledgecrcmedia.com.au/media/ anpernirrentye $12 \mathrm{~min} . \mathrm{html}$

Douglas, J. 2011. Learning from country-language and culture programs in bush schools for land management. Desert Knowledge CRC Report Number 72. CSIRO, Ninti One Ltd., Alice Springs Desert Park, Australia.

Douglas, J., and F. Walsh. 2008. Research governance convening the Merne Altyerr-ipenhe (Food from the Creation time) Reference Group. Pages 36-37 in M. Campbell and M. Christie, editors. Indigenous community engagement at Charles Darwin University. Uniprint NT, Darwin, Australia. [online] URL: http://www.cdu.edu.au/centres/spill//pdf/ ICE@CDU FINAL.pdf?q=centres/spil/pdf/ICE@CDU FINAL. pdf

Dussart, F. 2000. The politics of ritual in an aboriginal settlement: kinship, gender and the currency of knowledge. The Smithsonian Institution Press, Washington, D.C., USA.

Edwards, G., G. Allan, C. Brock, A. Duguid, K. Gabrys, and P. Vaarzon-Morel. 2008. Fire and its management in central Australia. The Rangeland Journal 30(1):109-121. http://dx. doi.org/10.1071/RJ07037

Ens, E. J., M. Finlayson, K. Preuss, S. Jackson, and S. Holcombe. 2012. Australian approaches for managing "country" using indigenous and non-indigenous knowledge. Ecological Management and Restoration 13(1):100-107. http://dx.doi.org/10.1111/j.1442-8903.2011.00634.x

Federal Court of Australia (FCA). 1999. Hayes v Northern Territory [1999]. FCA 1248 (9 September 1999). Federal Court of Australia (FCA), Sydney, Australia. [online] URL: http://www.austlii.edu.au/au/cases/cth/federal_ct/1999/1248. $\underline{\mathrm{html}}$

Flynn, F. 1963. Northern gateway. Devonshire Press, Sydney, Australia.

Garibaldi, A., and N. Turner. 2004. Cultural keystone species: implications for ecological conservation and restoration. Ecology and Society 9(3):1-18. [online] URL: http://www. ecologyandsociety.org/vol9/iss3/art1/

Gibson, C. C., E. Ostrom, and T. K. Ahn. 2000. The concept of scale and the human dimensions of global change: a survey. Ecological Economics 32(2):217-239. http://dx.doi.org/10.1016/ S0921-8009(99)00092-0

Gorman, J. T., A. D. Griffiths, and P. J. Whitehead. 2006. An analysis of the use of plant products for commerce in remote Aboriginal communities of northern Australia. Economic Botany 60(4):362-373.

Green, J. 2012. The Altyerre story-“Suffering badly by translation." Taja: The Australian Journal of Anthropology 23 (2):158-178. http://dx.doi.org/10.1111/j.1757-6547.2012.00179. $\underline{x}$

Green, J., with Laramba women. 2003. Anmatyerr Ayey Arnang-akert $=$ Anmatyerr Plant Stories. IAD Press, Alice Springs, Australia.

Greenfield, P. M. 2004. Weaving generations together: evolving creativity in the Maya of Chiapas. School of American Research Press, Santa Fe, New Mexico, USA.

Henderson, J., and V. Dobson. 1994. Eastern and Central Arrernte to English dictionary. IAD Press, Alice Springs, Australia.

Hercus, L., F. Hodges, and J. Simpson, editors. 2002. The land is a map: place names of indigenous origin in Australia. Pandanus Books, Research School of Pacific and Asian Studies, The Australian National University, Pacific Linguistics, Canberra, Australia.

Holmes, M. C. C., and W. (S. P.) Jampijinpa. 2013. Law for country: the structure of Warlpiri ecological knowledge and its application to natural resource management and ecosystem stewardship. Ecology and Society 18(3): 19. http://dx.doi. org/10.5751/ES-05501-180319

Institute for Aboriginal Development (IAD) Press. 2002. Central Australian Aboriginal languages-current distribution; A2 map. Institute for Aboriginal Development, Alice Springs, Australia.

James, D. 2005. Kinship with country: acts of translation in the cross-cultural performance space. A case study on the Anangu Pitjantjatjara lands of central Australia. Dissertation, Australian National University, Canberra, Australia. 
Johannes, R. E. 1998. The case for data-less marine resource management: examples from tropical nearshore finfisheries. Trends in Ecology and Evolution (Amsterdam) 13(6):243-246. http://dx.doi.org/10.1016/S0169-5347(98)01384-6

Johannes, R. E. 2000. Ignore fishers knowledge and miss the boat. Fish and Fisheries (Oxford, England) 1(3):257-271.

Johnson, S., Top End Working Group, Desert Working Group, and Technical Advisory Group. 2006. Indigenous ecological knowledge: a Northern Territory scoping study. NAILSMA and TSM-CRC. Prepared for the NT Natural Resource Management Board, Darwin, NT, Australia.

Jones, N. A., H. Ross, T. Lynam, P. Perez, and A. Leitch. 2012. Mental models: an interdisciplinary synthesis of theory and methods. Ecology and Society 16(1):46. [online] URL: http:// www.ecologyandsociety.org/vol16/iss 1/art46/

Kassam, K. A. S. 2010. Coupled socio-cultural and ecological systems at the margins: Arctic and alpine cases. Frontiers of Earth Science in China 4(1):89-98. http://dx.doi.org/10.1007/ s11707-010-0008-6

Laramba, community elders, school students, and J. Moloney. 2009. Our elders are teaching us about our country and our stories. Laramba School and Tangentyere Landcare, Alice Springs, Australia.

Latz, P. 1995. Bushfires and bushtucker: Aboriginal plant use in central Australia. IAD Press, Alice Springs, Australia.

Lowe, P. 2002. Hunters and trackers of the Australian desert. Rosenberg Publishing, Sydney, Australia.

Lyver, P., C. Jones, and H. Moller. 2009. Looking past the wallpaper: considerate evaluation of traditional environmental knowledge by science. Journal of the Royal Society of New Zealand 39(4):219-223. [online] URL: http://www. tandfonline.com/doi/abs/10.1080/03014220909510584 http:// dx.doi.org/10.1080/03014220909510584

Maru, Y., and J. Davies. 2011. Supporting cross-cultural brokers is essential for employment among Aboriginal people in remote Australia. The Rangeland Journal 33(4):327-338. http://dx.doi.org/10.1071/RJ11022

Marika, R., Y. Yunupingu, R. Marika-Mununggiritj, and S. Muller. 2009. Leaching the poison-the importance of process and partnership in working with Yolngu. Journal of Rural Studies 25(4):404-413. http://dx.doi.org/10.1016/j.

jrurstud.2009.05.007

McCarthy, F., F. de la Couer, E. Yantarranga, T. Busbridge, T. Bain, K. Webeck, B. Hynes, and R. Challinor. 2010. Women's talk ... looking after country is our responsibility too: NT women's land and sea management forum proceedings. Australian Government Department of
Environment, Water, Heritage and the Arts, Ross River, Alice Springs, Australia.

Merne Altyerr-ipenhe Group, J. Douglas, and F. Walsh. 2011. Aboriginal people, their knowledge and plants from central Australia: guidelines for ethical practice in bush foods research, development and industry. Merne Altyerr-ipenhe (Food from the Creation time) Reference Group, Desert Knowledge CRC, Alice Springs, Australia. [online] URL: http://www.nintione.com.au/resource/NintiOneResearchReport_71_BushFoodGuidelines.pdf

Moller, H., F. Berkes, P. Lyver, and M. Kislalioglu. 2004. Combining science and traditional ecological knowledge: monitoring populations for co-management. Ecology and Society 9(3): 2. [online] URL: http://www.ecologyandsociety. org/vol9/iss3/art2

Morse, J. 2005. Bush resources: opportunities for Aboriginal enterprise in Central Australia. Desert Knowledge CRC and Central Land Council, Alice Springs, Australia. [online] [online] URL: http://www.desertknowledgecrc.com.au/resource/ DKCRC-Report-02-Bush-Foods.pdf

Mowaljarlai, D. 1992. Wayrrull-Aboriginal traditional responsibility in cultural resource management in the northwest Kimberleys of Western Australia. Pages 179-190 in J. Birckhead, T. De Lacy, and L. Smith, editors. Aboriginal involvement in parks and protected areas. Australian Institute of Aboriginal and Torres Strait Islander Studies, Canberra, Australia.

Muller, S. 2012. "Two Ways": bringing indigenous and nonindigenous knowledges together. Pages 59-79 in J. Weir, editor. Country, native title and ecology. Australian National University e-press and Aboriginal History Incorporated (Monograph 24), Canberra, Australia.

Myers, F. 1986. Pintupi country, Pintupi self-sentiment, place and politics among Western Desert Aborigines. Smithsonian Institution Press and Australian Institute of Aboriginal Studies, Washington, D.C., USA; London, UK; Canberra, Australia.

Nabhan, G. 2000. Interspecific relationships affecting endangered species recognised by O'odham and Comc'aac ['over a] cultures. Ecological Applications 10(5):1288-1295.

Nash, D., and J. Simpson. 1990. Wakirti Warlpiri. A short dictionary of Eastern Warlpiri with grammatical notes. Kunayungku, Tennant Creek, Alekarenge. [online] URL: http://www.anu.edu.au/linguistics/nash/aust/wlp/wlp-lx-ref.html

Newman, J., and H. Moller. 2005. Use of Matauranga (Maori traditional knowledge) and science to guide a seabird harvest: getting the best of both worlds? Senri Ethnological Studies 67:303-321. 
Newsome, A. 1980. The eco-mythology of the red kangaroo in central Australia. Mankind 12:327-333.

Parlee, B., F. Berkes, and T. Gwich'in. 2005. Health of the land, health of the people: a case study on Gwich'in berry harvesting in northern Canada. EcoHealth 2(2):127-137.

Pavey, C. 2006. National recovery plan for the greater bilby, Macrotis lagotis. Northern Territory Deparment of Natural Resources, Environment and the Arts, Darwin, Australia. [online] URL: http://www.environment.gov.au/biodiversity/ threatened/publications/pubs/m-lagotis.pdf

Prober, S. M., M. H. O’Connor, and F. J. Walsh. 2011. Australian Aboriginal peoples' seasonal knowledge: a potential basis for shared understanding in environmental management. Ecology and Society 16(2): 12. [online] URL: http://www.ecologyandsociety.org/vol16/iss2/art12/

Raffles, H. 2002. Intimate knowledge. International Social Science Journal 54(173):325-335. http://dx.doi. org/10.1111/1468-2451.00385

Roberts, M. 2012. Mind maps of the Maori. GeoJournal 77 (6):741-751. http://dx.doi.org/10.1007/s10708-010-9383-5

Rogoff, B. 2003. The cultural nature of human development. Oxford University Press, New York, New York, USA. http:// dx.doi.org/10.1037/e612832007-002

Rowley, K. G., K. O'Dea, I. Anderson, R. McDermott, K. Saraswati, R. Tilmouth, I. Roberts, J. Fitz, Z. Wang, A. Jenkins, J. D. Best, Z. Wang, and A. Brown. 2008. Lower than expected morbidity and mortality for an Australian Aboriginal population: 10-year follow-up in a decentralised community. Medical Journal of Australia 188(5):283-287. [online] URL: https://www.mja.com.au/journal/2008/188/5

Rubuntja, W., J. Green, and T. Rowse. 2002. The town grew up dancing: the life and art of Wenton Rubuntja. IAD Press, Alice Springs, Australia.

Sherry, E., and H. Myers. 2002. Traditional environmental knowledge in practice. Society and Natural Resources 15 (4):345-358. http://dx.doi.org/10.1080/089419202753570828

Stafford Smith, M. 2008. The "desert syndrome"-causallylinked factors that characterise outback Australia. The Rangeland Journal 30(1):3.

Stanner, W. E. H. 1965. Aboriginal territorial organisation: estate, range, domain and regime. Oceania 36(1):1-26.

Strehlow, T. 1970. Geography and the totemic landscape in central Australia: a functional study. Pages 92-128 in R. Berndt, editor. Australian aboriginal anthropology: modern studies in the social anthropology of the Australian aborigines. Australian Institute of Aboriginal Studies, Canberra, Australia.
Strehlow, T. G. H. 1965. Culture, social structure and environment in central Australia. Pages 121-145 in R. Berndt and C. Berndt, editors. Aboriginal man in Australia. Angus and Robertson, Sydney, Australia.

Strydom, P. 2011. The cognitive and metacognitive dimensions of socal and political theory. Pages 328-349 in G. Delanty and S. P. Turner, editors. Routledge international handbook of contemporary social and political theory. Routledge, New York, New York, USA.

Sutton, P., editor. 1988. Dreamings: the art of Aboriginal Australia. Viking Penguin Books, Melbourne, Australia.

Sutton, P. 1995. Country: Aboriginal boundaries and land ownership in Australia. Aboriginal History Monograph Series, Canberra, Australia.

Tangentyere Landcare. 2007. Land and learning: a central Australian environmental education program for Aboriginal schools and others. Report Tangentyere Council, Alice Springs, Australia.

Telfer, W. and M. Garde. 2006. Indigenous knowledge of rock kangaroo ecology in western Arnhem Land, Australia. Human Ecology 34(3):379-406. http://dx.doi.org/10.1007/s10745-006-9023-3

Thompson, T. K. (M. Turpin, compiler.) 2003. Growing up Kaytetye: stories told by Tommy Kngwarraye Thompson. IAD Press, Alice Springs, Australia.

Tilmouth, V. K., and L. N. Abbott. (J. Green, compiler.) 2007. Anengkerr angkety: dreaming stories. Page 4 in J. N. Cook, editor. Anengkerr angkety: dreaming stories. Batchelor Press, Alice Springs, Australia.

Tobias, T. 2010. Living proof: the essential data collection guide for indigenous land use and occupancy map surveys. Ecotrust Canada, Vancouver, British Columbia, Canada.

Toohey, J. 1980. Anmatjirra and Alwawarra land claim to the Utopia pastoral lease. Report by the Aboriginal Land Commissioner, Mr. Justice Toohey, to the Minister for Aboriginal Affairs and the Administrator of the Northern Territory. Australian Government Publishing Service, Canberra, Australia.

Turner, M. 2005a. Bush foods: Arrernte foods from central Australia. Second edition. IAD Press, Alice Springs, Australia.

Turner, M. 2005b. Everything comes from the land. IAD Press, Alice Springs, Australia.

Turner, M. K., and B. McDonald. 2010. Iwenhe Tyerrtyewhat it means to be an Aboriginal person. IAD Press, Alice Springs, Australia.

Turner, N., R. Gregory, C. Brooks, L. Failing, and T. Satterfield. 2008. From invisibility to transparency: 
identifying the implications. Ecology and Society 13(2): 7. [online] URL: http://www.ecologyandsociety.org/vol13/iss2/ $\underline{\operatorname{art} 7 /}$

Wallace, K. K., and J. Lovell. 2009. Listen deeply, let these stories in. IAD Press, Alice Springs, Australia.

Walsh, F. 1992. The relevance of some aspects of Aboriginal subsistence activities to the management of national parks: in reference to Martu people of the Western Desert. Pages 7598 in J. Birckhead, T. De Lacy, and L. Smith, editors. Aboriginal involvement in parks and protected areas. Aboriginal Studies Press, Canberra, Australia.

Walsh, F. 2008. To hunt and to hold: Martu Aboriginal people's uses and knowledge of their country, with implications for co-management in Karlamilyi (Rudall River) National Park and the Great Sandy Desert, Western Australia. Dissertation. Schools of Social and Cultural Studies (Anthropology) and Plant Biology (Ecology), The University of Western Australia, Perth, Australia. [online] URL: http:// www.desertknowledgecrc.com.au/resource/To-hunt-and-tohold_Martu-Aboriginal-peoples-uses-and-knowledge-of-theircountry.pdf

Walsh, F., and J. Douglas. 2009. Harvester-trader exchanges: critical elements of small-scale commercial bush produce harvesting in central Australia sustained to at least 2006 Pages 20-49 in M. Ryder, F. Walsh, J. Douglas, M. Waycott, H. Robson, Z. Singh, M. Majer, T. Collins, J. White, and B. Cheers, editor. Sustainable bush produce systems. Desert Knowledge CRC, Alice Springs, Australia. [online] URL: http://nintione.com.au/publication/dkcrc-0706

Walsh, F., and J. Douglas. 2011. No bush foods without people: the essential human dimension to the sustained trade in native plant products from desert Australia. The Rangeland Journal 33:395-416. http://dx.doi.org/10.1071/RJ11028

Walsh, F., and P. Mitchell, editors. 2002. Planning for country: cross-cultural approaches to decision making on Aboriginal lands. Jukurrpa Books/IAD Press, Alice Springs, Australia.

Warlukurlangu Artists. 1992. Kuruwarri: Yuendumu doors. Aboriginal Studies Press, Canberra, Australia.

Wehi, P. and W. Wehi. 2009a. Traditional plant harvesting in contemporary fragmented and urban landscapes. Conservation Biology 24(2):594-604.

Wehi, P., H. Whaanga, and T. Roa. 2009b. Missing in translation: Maori language and oral tradition in scientific analyses of traditional ecological knowledge. Journal of the Royal Society of New Zealand 39(4):201-204.
Wilson, G., M. Edwards, and J. Smits. 2010. Support for indigenous wildlife management in Australia to enable sustainable use. Wildlife Research 37(3):255-263. http://dx. doi.org/10.1071/WR09130

Wohling, M. 2009. The problem of scale in indigenous knowledge: a perspective from Northern Australia. Ecology and Society 14(1):1-14. [online] URL: http://www. ecologyandsociety.org/vol14/iss1/art1/

Woods, G., and M. Turpin. 2008. Thipele arle ileme akertethings that birds let you know about. AIATIS, Central Land Council, Alice Springs Desert Park, Australia.

Woodward, E., S. Jackson, M. Finn, and P. M. McTaggard. 2012. Utilising Indigenous seasonal knowledge to understand aquatic resource use and inform water resource management in northern Australia Ecological Management and Restoration 13(1):58-64

Yates, P. 2009. The bush foods industry and poverty alleviation in Australia. Dialogue 2009(2):47-56. 


\section{Appendix 1.}

Veronica has more than 60 years experience in species harvesting and ecosystem-based monitoring. This includes formative childhood years when her family hunted and gathered on lands east of Alice Springs with regular foot-based journeys of more than $200 \mathrm{~km}$ distance. She is the most published of any central Australian Aboriginal author (e.g Henderson and Dobson 1994, Dobson and Nano 2005, Dobson et al. 2008). She was awarded a 'Member of the Order of Australia' by the Australian Governor-General.

Whilst some might see her as a sole authority, Veronica speaks humbly of her knowledge as inherited from her grandparents and forbearers (Dobson 2007). Josie is a Wardaman woman married into an Arrernte family. She managed an indigenous publishing house specialising in language and cultural books. Her research foci are on traditional knowledge within Aboriginal education (Douglas 2011) and the lives of Aboriginal youth. Fiona has 23 years practical experience working with various desert Aboriginal groups and organisations (e.g. Walsh 1992, Walsh 2008, Walsh and Mitchell 2002). She is now a researcher with a strong practical orientation.

Dobson is highly fluent in Arrernte and English; we three authors talked mainly in English. We recognise that many meanings are lost in the translation and transcription of practices and concepts to paper (Wehi et al. 2009b). Also essential to our methods is trans-disciplinary research with linguists, anthropologists and geographers. We three authors compiled the findings section of this paper. The paper was written by Fiona and Josie then re-read by the three of us. 